\title{
Angiotensin Il-induced endothelial dysfunction is temporally linked with increases in interleukin-6 and vascular macrophage accumulation
}

\author{
Jessica R. Gomolak ${ }^{1}$ and Sean P. Didion ${ }^{1,2 *}$ \\ ${ }^{1}$ Department of Pharmacology, The University of Mississippi Medical Center, Jackson, MS, USA \\ ${ }^{2}$ Department of Neurology, The University of Mississippi Medical Center, Jackson, MS, USA
}

\section{Edited by:}

Timothy R. Nurkiewicz, West

Virginia University, USA

\section{Reviewed by:}

Amanda Jo LeBlanc, University of

Louisville and Jewish Hospital, USA

Matthew Zimmerman, University of

Nebraska Medical Center, USA

\section{*Correspondence:}

Sean P. Didion, Departments of

Pharmacology and Neurology, The

University of Mississippi Medical

Center, Arthur C. Guyton Laboratory

Research Building, G311-313, 2500

North State Street, Jackson,

MS 39216-4505, USA

e-mail:didionlab@gmail.com
Angiotensin II (Ang II) is associated with vascular hypertrophy, endothelial dysfunction and activation of a number of inflammatory molecules, however the linear events involved in the development of hypertension and endothelial dysfunction produced in response to Ang II are not well defined. The goal of this study was to examine the dose- and temporal-dependent development of endothelial dysfunction in response to Ang II. Blood pressure and responses of carotid arteries were examined in control (C57BI/6) mice and in mice infused with 50,100,200,400, or $1000 \mathrm{ng} / \mathrm{kg} / \mathrm{min}$ Ang II for either 14 or 28 Days. Infusion of Ang II was associated with graded and marked increases in systolic blood pressure and plasma Ang II concentrations. While low doses of Ang II (i.e., 50 and $100 \mathrm{ng} / \mathrm{kg} / \mathrm{min}$ ) had little to no effect on blood pressure or endothelial function, high doses of Ang II (e.g., $1000 \mathrm{ng} / \mathrm{kg} / \mathrm{min}$ ) were associated with large increases in arterial pressure and marked impairment of endothelial function. In contrast, intermediate doses of Ang II (200 and $400 \mathrm{ng} / \mathrm{kg} / \mathrm{min}$ ) while initially having no effect on systolic blood pressure were associated with significant increases in pressure over time. Despite increasing blood pressure, $200 \mathrm{ng} / \mathrm{kg} / \mathrm{min}$ had no effect on endothelial function, whereas $400 \mathrm{ng} / \mathrm{kg} / \mathrm{min}$ produced modest impairment on Day 14 and marked impairment of endothelial function on Day 28. The degree of endothelial dysfunction produced by 400 and $1000 \mathrm{ng} / \mathrm{kg} / \mathrm{min}$ Ang II was reflective of parallel increases in plasma IL-6 levels and vascular macrophage content, suggesting that increases in arterial blood pressure precede the development of endothelial dysfunction. These findings are important as they demonstrate that along with increases in arterial pressure that increases in IL-6 and vascular macrophage accumulation correlate with the impairment of endothelial function produced by Ang II.

Keywords: carotid artery, endothelium, interleukin-6, vascular hypertrophy, mice

\section{INTRODUCTION}

It is well documented that angiotensin II (Ang II), the main effector peptide of the renin-angiotensin system, produces hypertension, oxidative stress, vascular hypertrophy, and endothelial dysfunction (Bean et al., 1979; Brown et al., 1981; Didion et al., 2002, 2005; Didion and Faraci, 2003; Cassis et al., 2004; Crowley et al., 2005; Schrader et al., 2007). In humans, several forms of hypertension are associated with increases in plasma Ang II levels, such as renovascular hypertension and hypertension due to renin secreting tumors (Catt et al., 1969, 1971; Garovic and Textor, 2005; Beevers et al., 2008). Genetic and experimental models, such as mice which express human renin and angiotensinogen, renovascular hypertension (e.g., 2-kidney, 1-clip) and infusion of exogenous Ang II, are commonly used approaches to model human hypertension associated with increases in Ang II (Bean et al., 1979; Johns et al., 1996; Didion et al., 2000, 2002, 2005).

In the last couple of decades the use of Ang II infusion has increased dramatically. It has been estimated that infusion of Ang II is the most commonly used model of hypertension as evidenced by use in nearly half of all NIH grants involving the use of an experimental model of hypertension (Galis et al., 2013). The popularity of the Ang II infusion model has been driven in part, due to the ease of use, but also due to the advent of technologies associated with the generation of genetically-altered mice and more recently genetically-altered rats (Smithies and Kim, 1994; Geurts et al., 2009). The combination of the Ang II model and genetic technologies has provided a wealth of information regarding genes that contribute to the development of hypertension and related vascular sequalae, including the role of oxidative stress and inflammatory cytokines as well as inflammatory cell types in promoting vascular hypertrophy and endothelial dysfunction (Bush et al., 2000; Wang et al., 2001; Ryan et al., 2004; Didion et al., 2005, 2009; Guzik et al., 2007; Schrader et al., 2007; Madhur et al., 2010; Barhoumi et al., 2011).

Recently, it has been suggested that there may be an overreliance on the Ang II model considering that the model is not reflective of primary (essential) hypertension, which accounts for the majority of hypertension in humans (Galis et al., 2013). While 
the Ang II infusion model is most reflective of secondary forms of hypertension, it should be noted that a major target of antihypertensive therapy in essential hypertension in humans has been directed toward limiting Ang II signaling (e.g., ACE inhibitors and angiotensin receptor blockers) (Sica, 2010; Hanselin et al., 2011). Thus, the Ang II infusion model clearly has direct relevance to human hypertension irrespective of etiology.

As with any model of human disease, there are both strengths and limitations associated with the Ang II infusion model. For example, Ang II infusion can produce immediate effects on blood pressure, which is a strength of the model, but also a limitation, as hypertension in humans usually develops over decades rather than minutes or days. The use of high doses of Ang II, particularly in the mouse, has been questioned as it relates to plasma concentrations observed in human hypertension. While is difficult to extrapolate between studies in different species, any potential comparison is complicated by the fact that in the majority of studies with Ang II infusion in mice either do not measure or do not report plasma Ang II levels (Bush et al., 2000; Ryan et al., 2004; Lee et al., 2006; Guzik et al., 2007; Didion et al., 2009; Barhoumi et al., 2011). Another limitation is that it is often difficult to make direct comparisons between studies, as there is marked variability between studies in terms of the dose (anywhere from 490 up to as high as $3600 \mathrm{ng} / \mathrm{kg} / \mathrm{min}$ Ang II) and the length of time (as short as 3,7 , or 10 days and as long as 28 days) in which Ang II is infused (Bean et al., 1979; Didion et al., 2005, 2009; Lee et al., 2006; Guzik et al., 2007; Schrader et al., 2007; Madhur et al., 2010; Barhoumi et al., 2011). This is also complicated by the fact that the majority of studies in the literature examine single doses at single time points thus providing limited insight into the temporal development of hypertension and vascular dysfunction produced in response to Ang II (Bush et al., 2000; Ryan et al., 2004; Lee et al., 2006; Guzik et al., 2007; Didion et al., 2009; Barhoumi et al., 2011).

We had several goals for the present study. First, we sought to determine the effects of Ang II on blood pressure and plasma Ang II levels. Second, we sought to determine whether hypertension per se promoted the impairment of endothelial function or vice versa. Finally, we sought to determine the sequential and temporal activation of inflammatory molecules in the development of endothelial dysfunction in response to Ang II. We focused our studies of vascular function to the carotid artery, as carotid artery disease and hypertension are both important risk factors for ischemic stroke (Go et al., 2013; Kernan et al., 2014).

\section{METHODS \\ ANIMALS}

Male C57Bl/6 mice (\#000664; $n=46)$ were obtained from the Jackson Laboratory (Bar Harbor, ME) and were randomly selected to either one of two groups (i.e., control or Ang IIinfused group). Mice selected to the Ang II-infused group were implanted with either a 14 Day (Alzet ${ }^{\circledR}$ Model 1002; DURECT $^{\text {тм }}$ Corporation, Cupertino, CA) or a 28 Day Alzet $^{\circledR}$ Model 1004) micro-osmotic pump containing 50, 100, 200, 400, or $1000 \mathrm{ng} / \mathrm{kg} / \mathrm{min}$ Ang II as described previously (Didion et al., 2005; Schrader et al., 2007). All experimental protocols conform to the NIH Guide for the Care and Use of Laboratory Animals and were approved by the Institutional Animal Care and Use Committee at the University of Mississippi Medical Center.

\section{SYSTOLIC BLOOD PRESSURE MEASUREMENTS}

Systolic blood pressure was measured using tail-cuff plethysmography (Visitech Systems BP-2000 Series II Blood Pressure Analysis System $^{\mathrm{TM}}$, Apex, NC) in a manner similar to that described previously by our laboratory (Didion et al., 2005; Schrader et al., 2007). Briefly, mice were trained for a period of 5 consecutive days in which blood pressure was measured (30 measurements per day) but not recorded. Following this training period, blood pressure was measured for another 3 consecutive days, recorded and averaged. The blood pressure measured during this period is reported as baseline (Day 0). Blood pressure was then measured on Days 3, $7,14,21$, and 28 in both control and Ang II-infused groups.

\section{STUDIES OF ENDOTHELIAL FUNCTION IN CAROTID ARTERY}

Depending on whether mice were implanted with a 14 or 28 Day minipump they and their respective controls were euthanized on either Day 14 or 28 with pentobarbital sodium $(150 \mathrm{mg} / \mathrm{kg}$ ip). Arterial blood was collected for measurements of plasma Ang II and IL-6 levels. Bestatin ${ }^{\circledR}$ (Sigma Chemical, St Louis, MO) was added to the blood samples in order prevent proteolysis of angiotensinogens. Both common carotid arteries as well as the thoracic aorta were carefully dissected and removed for studies of endothelial function as well as measurement of vascular macrophage content and medial cross-sectional area (CSA), respectively.

For studies of endothelial function, carotid arteries were placed in Kreb's buffer with the following composition $(\mathrm{mmol} / \mathrm{L})$ : $\mathrm{NaCl}$ 118.3, $\mathrm{KCl}$ 4.7, $\mathrm{CaCl}_{2}$ 2.5, $\mathrm{MgSO}_{4} 1.2, \mathrm{KH}_{2} \mathrm{PO}_{4}$ 1.2, $\mathrm{NaHCO}_{3} 25$, glucose 11. Loose connective tissue was removed and then each carotid artery was cut into two vascular rings each 3-4 $\mathrm{mm}$ in length. Vascular rings were connected to a force transducer to measure isometric tension (contraction and relaxation) in individual organ baths containing $20 \mathrm{ml}$ Krebs buffer maintained at $37^{\circ} \mathrm{C}$ and gassed with a mixture of $95 \% \quad \mathrm{O}_{2}$ and $5 \% \mathrm{CO}_{2}$. Following a 45-min equilibration period vessels were pre-contracted $(50-60 \%$ of maximum) with the thromboxane analog, 9,11-dideoxy-11aepoxymethanprotaglandin F2 $\alpha$ (U46619). After achieving a stable contraction plateau, concentration-response curves were generated to acetylcholine (an endothelium-dependent agonist; $0.01-100 \mu \mathrm{mol} / \mathrm{L}$ ) and to nitroprusside (an endotheliumindependent agonist; $0.01-100 \mu \mathrm{mol} / \mathrm{L}$ ). Concentration-response curves were recorded using PowerLab ${ }^{\circledR}$ data acquisition systems and analyzed off-line with LabChart ${ }^{\circledR}$ software (ADInstruments, Colorado Springs, CO).

\section{MEASUREMENT OF VASCULAR HYPERTROPHY}

For measurements of medial CSA aortas were fixed in $4 \%$ buffered paraformaldhyde and then processed and embedded in paraffin while maintaining vessels in a cross-sectional orientation. Aortas were sectioned (7 microns), placed on microscope slides, stained with hematoxalin and eosin and then cover slipped. Sections were viewed and imaged using a Nikon Eclipse $\mathrm{N} i-\mathrm{U}$ microscope. Medial CSA of the carotid artery was determined 
using Nikon NIS-Elements software as described previously (Schrader et al., 2007).

\section{MEASUREMENT OF PLASMA ANG II AND IL-6 LEVELS}

Plasma levels of Ang II and IL-6 were measured using a highsensitivity mouse Ang II (Enzo, New York, NY) and IL-6 (R\&D Biosciences, Minneapolis, MN) ELISA kit, respectively, according to manufacturer's instructions.

\section{MEASUREMENT OF VASCULAR MACROPHAGES}

For measurement of vascular macrophage content, anterior segments of the left common carotid artery were frozen in optimal cutting temperature (O.C.T., Tissue-Tek, Sakura Finetek, USA) compound. Carotid arteries were sectioned using a cryostat and placed on glass microscope slides, boiled for $20 \mathrm{~min}$ in $10 \mathrm{mM}$ citrate buffer, and blocked in 5\% goat serum for $1 \mathrm{~h}$ at room temperature. Slides were incubated with a general macrophage (CD68) primary antibody (Abcam, ab955) overnight at $4^{\circ} \mathrm{C}$. Prior to the horseradish peroxidase conjugated secondary antibody incubation slides were treated with $0.3 \%$ hydrogen peroxide followed by incubation with 3,3'-diaminobenzidine (DAB) for $10 \mathrm{~min}$. Slides were counterstained with hematoxylin and CD68 positive cells were examined and counted (at a magnification of 40x) using light microscopy (Nikon Eclipse Ni microscope, Tokyo, Japan).

\section{DRUGS}

Acetylcholine, Ang II (human, acetate salt), and nitroprusside were obtained from Sigma (St. Louis, MO) and were dissolved in saline. U46619 (in methyl acetate) was obtained from Cayman Chemical (Ann Arbor, MI) and evaporated with 100\% nitrogen gas and re-suspended in $100 \%$ ethanol with subsequent dilutions being made with saline. All other reagents were of standard laboratory grade.

\section{STATISTICAL ANALYSIS}

All data are expressed as Means \pm SE. Comparisons of blood pressure were made using Two-Way ANOVA. Responses to acetylcholine and nitroprusside are expressed as a percent relaxation to U46619-induced contraction and were compared using Two-Way ANOVA for repeated measures followed by Bonferroni post-hoc test. Medial cross-sectional area, plasma Ang II and IL-6 concentration, as well as vascular macrophage content were compared using One-Way ANOVA. Statistical significance was accepted at $P<0.05$.

\section{RESULTS \\ ANG II INFUSION IS ASSOCIATED WITH DOSE-DEPENDENT INCREASES IN BLOOD PRESSURE}

Baseline systolic blood pressure was similar $(P>0.05)$ in all groups of mice prior to infusion of Ang II (Day 0 ) and collectively averaged $116 \pm 5 \mathrm{mmHg}$. Ang II infusion was associated with a graded pressor response that was dependent on both the dose and length of time of Ang II infusion (Figure 1). For example, infusion of either 50 or $100 \mathrm{ng} / \mathrm{kg} / \mathrm{min}$ Ang II had no effect $(P>0.05)$ on systolic blood pressure. Blood pressure in mice infused with 50 and $100 \mathrm{ng} / \mathrm{kg} / \mathrm{min}$ was similar to that in control mice on Days 14 and 28. Infusion of $200 \mathrm{ng} / \mathrm{kg} / \mathrm{min}$ Ang II was associated with a

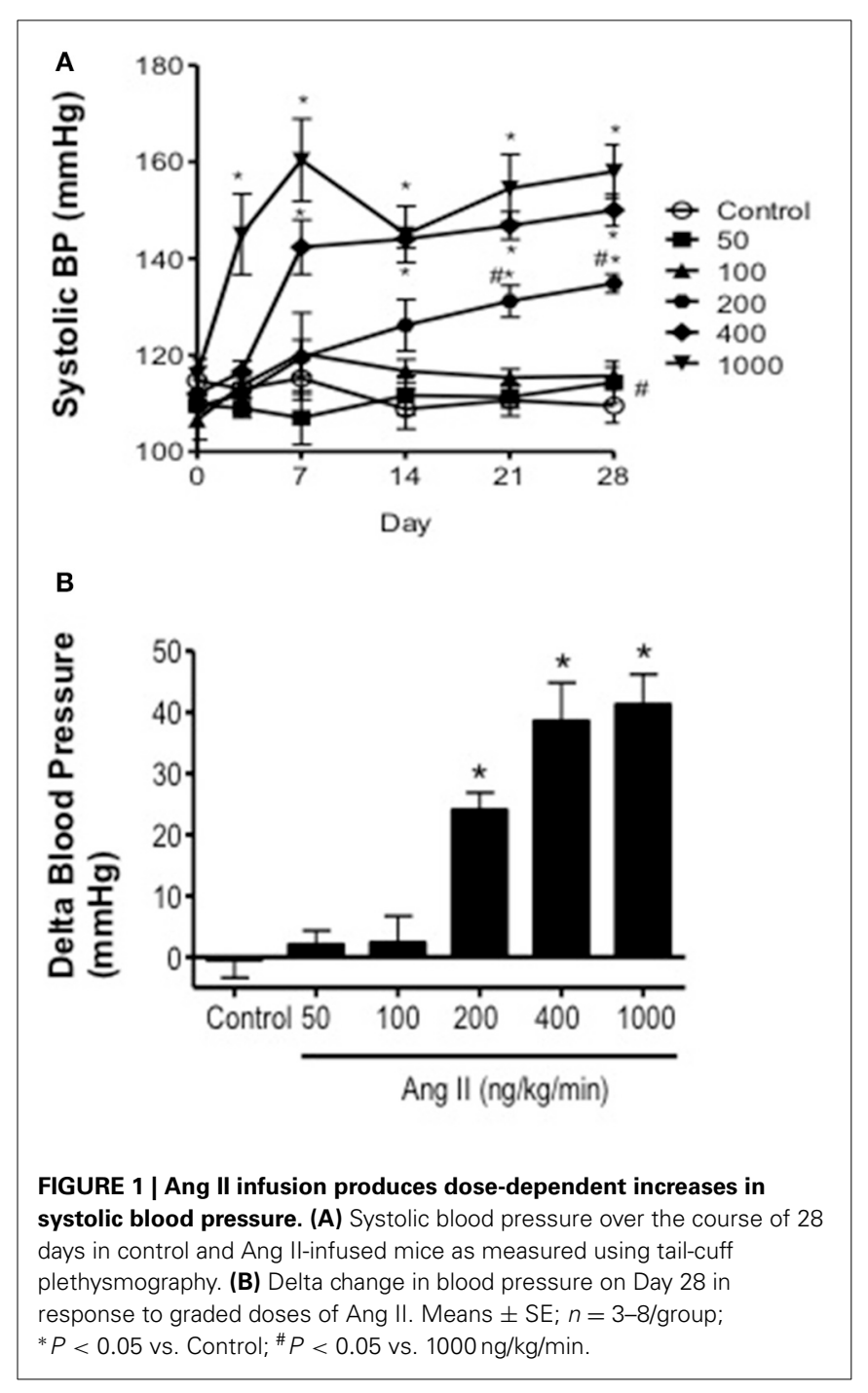

gradual increase in systolic pressure, which began by Day 14 and reached a maximum of $134 \pm 2 \mathrm{mmHg}$ on Day 28. Infusion of $400 \mathrm{ng} / \mathrm{kg} / \mathrm{min}$ Ang II was also associated with a gradual increase in blood pressure that began on Day 7 reaching a maximum of $150 \pm 3 \mathrm{mmHg}$ on Day 28 (Figure 1). In contrast, Infusion of Ang II at a rate of $1000 \mathrm{ng} / \mathrm{kg} / \mathrm{min}$ was associated with a marked and immediate increase in blood pressure $(136 \pm 6 \mathrm{mmHg}$ on Day 3$)$ that was maintained throughout the infusion period reaching a maximum of $158 \pm 6 \mathrm{mmHg}$ on Day 28 .

\section{ANG II INFUSION IS ASSOCIATED WITH DOSE-DEPENDENT INCREASES IN PLASMA ANG II LEVELS}

Ang II levels in control mice were $49 \pm 12 \mathrm{pg} / \mathrm{ml}$ (Figure 2). In mice infused with 50 and $100 \mathrm{ng} / \mathrm{kg} / \mathrm{min}$ Ang II, plasma Ang II levels were similar $(P>0.05)$ to that in control mice and averaged $63 \pm 12$ and $112 \pm 7 \mathrm{pg} / \mathrm{ml}$, respectively. Infusion of 200, 400, and $1000 \mathrm{ng} / \mathrm{kg} / \mathrm{min}$ Ang II was associated with dose-dependent increases in plasma Ang II (Figure 2). For example, plasma Ang II levels in mice infused with 200 and $400 \mathrm{ng} / \mathrm{kg} / \mathrm{min}$ were $173 \pm 56$ and $237 \pm 46 \mathrm{pg} / \mathrm{ml}$, respectively and were significantly different 

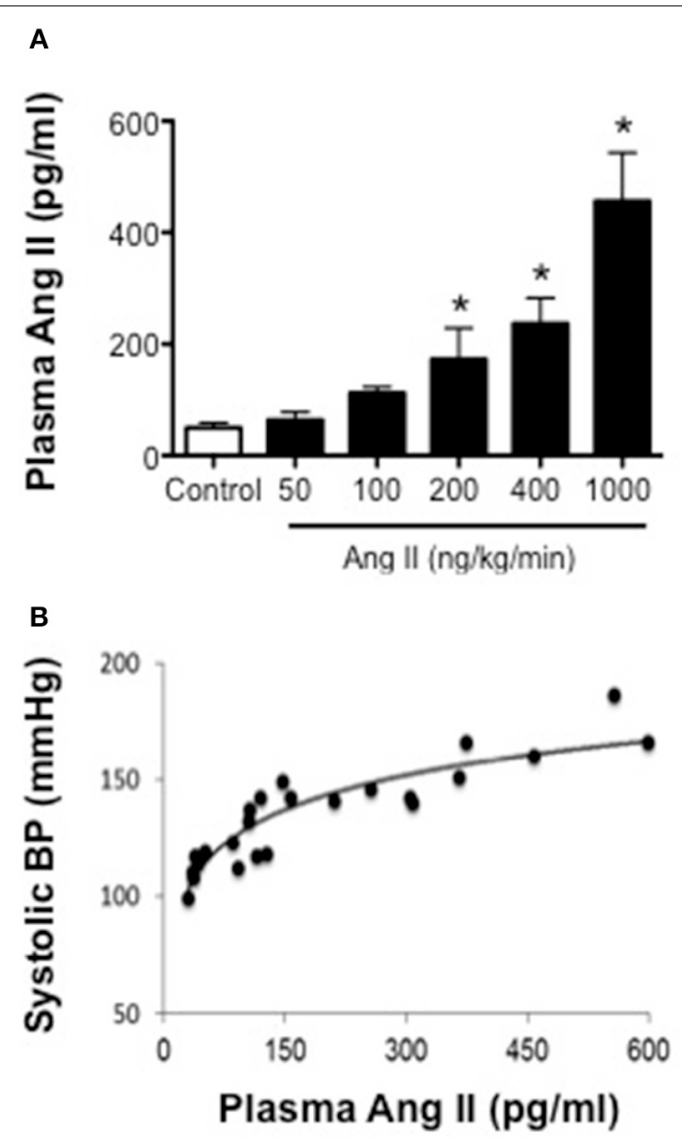

FIGURE 2 | Systolic blood pressure is positively associated with plasma Ang II levels. (A) Plasma Ang II levels as measured by ELISA on Day 28. (B) Plasma Ang II concentration-blood pressure response curve $\left(R^{2}=0.8206\right)$. Means \pm SE; $n=3-8 /$ group; ${ }^{*} P<0.05$ vs. Control.

$(P<0.05)$ from Ang II levels in control mice but were not different $(P>0.05)$ from each other. Infusion of $1000 \mathrm{ng} / \mathrm{kg} / \mathrm{min}$ Ang II was associated with the greatest increase in plasma Ang II levels (i.e., $456 \pm 106 \mathrm{pg} / \mathrm{ml}$ ), which was significantly higher than that in either control mice or any of the other Ang II-infused groups (Figure 2). When plasma Ang II levels were plotted against blood pressure, we found that there was a strong correlation between plasma Ang II levels and systolic blood pressure (Figure 2).

\section{ANG II INFUSION IS ASSOCIATED WITH DOSE- AND TIME-DEPENDENT REDUCTIONS IN ENDOTHELIAL FUNCTION}

In carotid arteries from control mice, acetylcholine produced concentration-dependent relaxation that was similar on Day 14 as that observed on Day 28 (Figures 3, 4). For example, $100 \mu \mathrm{mol} / \mathrm{L}$ acetylcholine produced $95 \pm 3$ and $97 \pm 2 \%$ relaxation in carotid arteries from control mice on Day 14 and 28 respectively. Acetylcholine also produced relaxation in mice infused with 50 or $100 \mathrm{ng} / \mathrm{kg} / \mathrm{min}$ of Ang II that was similar $(P>0.05)$ to that in control mice both on Day 28 (Figure 3). For example, $100 \mu \mathrm{mol} / \mathrm{L}$ acetylcholine produced $89 \pm 7 \%$ relaxation in mice infused with $50 \mathrm{ng} / \mathrm{kg} / \mathrm{min}$ Ang II and $100 \pm 4 \%$ relaxation in mice infused with $100 \mathrm{ng} / \mathrm{kg} / \mathrm{min}$ Ang II on Day 28.

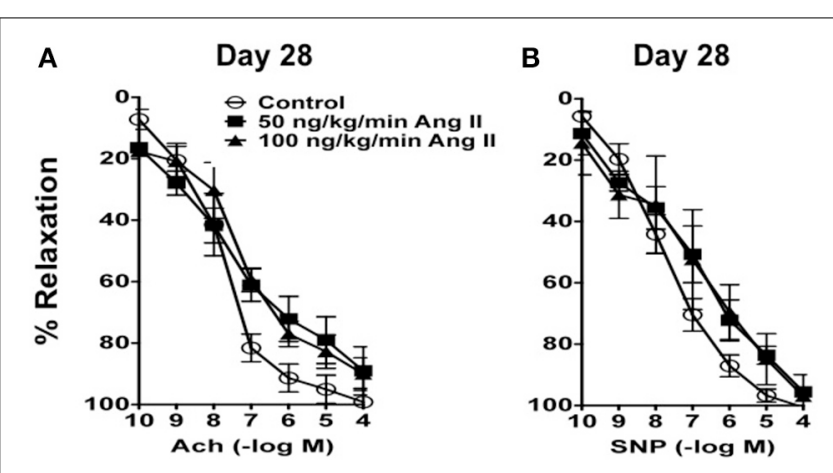

FIGURE 3 | (A) Endothelium-dependent responses to acetylcholine (Ach) and (B) Endothelium-independent responses to nitroprusside (SNP) in carotid arteries from control mice and mice infused with 50 or $100 \mathrm{ng} / \mathrm{kg} / \mathrm{min}$ of Ang $I I$ for 28 days. Means \pm SE; $n=3 /$ group; $P>0.05$.

In contrast, Ang II was associated with endothelial dysfunction in mice infused with 200, 400, and $1000 \mathrm{ng} / \mathrm{kg} / \mathrm{min}$ Ang II that was dependent on both the dose and length of time of Ang II infusion (Figure 4). For example, $200 \mathrm{ng} / \mathrm{kg} / \mathrm{min}$ Ang II was associated with a small rightward shift in the concentration-response curve to acetylcholine. However, $200 \mathrm{ng} / \mathrm{kg} / \mathrm{min}$ Ang II had no effect $(P>0.05)$ on the relaxation produced by the highest concentration of acetylcholine (e.g., $100 \mathrm{mmol} / \mathrm{L}$ acetylcholine produced 89 \pm 2 and $81 \pm 4 \%$ relaxation on Day 14 and 28 , respectively, in carotid arteries from mice infused with $200 \mathrm{ng} / \mathrm{kg} / \mathrm{min}$ ).

Similarly, relaxation to acetylcholine in carotid arteries from mice infused with $400 \mathrm{ng} / \mathrm{kg} / \mathrm{min}$ Ang II was associated with a moderate degree of impairment of endothelial function on Day 14, however with time the degree of impairment was significantly greater $(P<0.05)$ on Day 28 (Figure 4$)$. For example, $100 \mu \mathrm{mol} / \mathrm{L}$ acetylcholine produced $80 \pm 6$ and $55 \pm 6 \%$ relaxation in carotid artery from mice infused with $400 \mathrm{ng} / \mathrm{kg} / \mathrm{min}$ Ang II for 14 and 28 days, respectively.

Finally, $1000 \mathrm{ng} / \mathrm{kg} / \mathrm{min}$ Ang II was associated with marked impairment of endothelial function in response to acetylcholine by Day 14 and was similar to that with infusion of $1000 \mathrm{ng} / \mathrm{kg} / \mathrm{min}$ Ang II for 28 Days (Figure 4). For example, $1000 \mathrm{ng} / \mathrm{kg} / \mathrm{min}$ Ang II was associated with $56 \pm 7$ and $58 \pm 6 \%$ relaxation on Day 14 and 28, respectively. Endothelium-independent responses to nitroprusside were normal in control mice and mice infused with 50,100 , and $200 \mathrm{ng} / \mathrm{kg} / \mathrm{min}$, however responses to nitroprusside in carotid arteries from mice infused with 400 and $1000 \mathrm{ng} / \mathrm{kg} / \mathrm{min}$ were significantly reduced as compared to those in control mice (data not shown).

\section{ANG II INFUSION WAS ASSOCIATED WITH VASCULAR HYPERTROPHY}

Ang II was associated with vascular hypertrophy only with infusion of 200, 400, and $1000 \mathrm{ng} / \mathrm{kg} / \mathrm{min}$ Ang II (Figure 5). Surprisingly, the effect of Ang II was for the most part all-or-none, with low doses of Ang II (i.e., 50 and $100 \mathrm{ng} / \mathrm{kg} / \mathrm{min}$ ) having no effect on medial CSA, whereas 200, 400, and $1000 \mathrm{ng} / \mathrm{kg} / \mathrm{min}$ were all associated with significant increases in medial CSA. The degree of hypertrophy produced by all three doses was of similar magnitude and appeared to occur by Day 14 and did not appear to increase any further at Day 28 (Figure 5). 

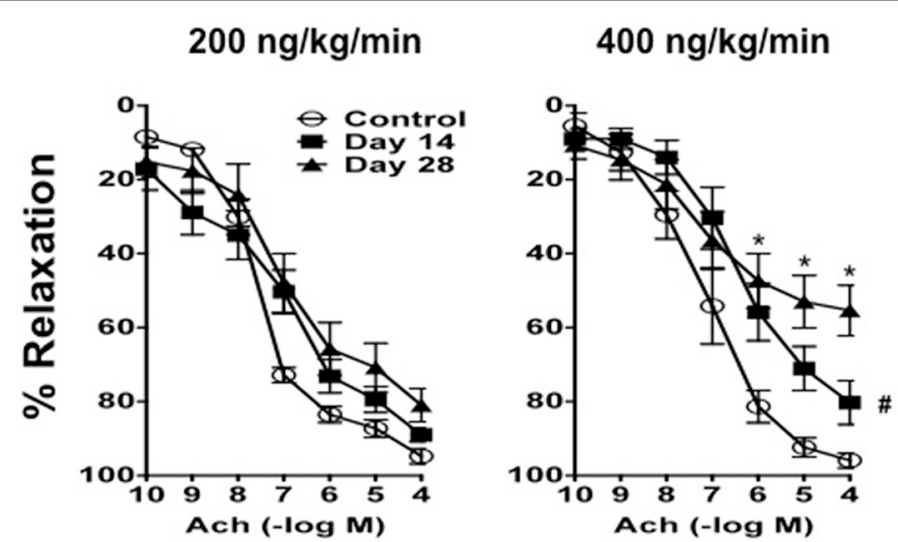

\section{$1000 \mathrm{ng} / \mathrm{kg} / \mathrm{min}$}

FIGURE 4 | Ang II produces impairment of endothelial function in a dose- and time-dependent manner. Responses to acetylcholine (Ach) in carotid arteries from control mice and mice infused with $200 \mathrm{ng} / \mathrm{kg} / \mathrm{min}$, $400 \mathrm{ng} / \mathrm{kg} / \mathrm{min}$, or $1000 \mathrm{ng} / \mathrm{kg} / \mathrm{min}$ of Ang II for 14 or 28 days. Means \pm SE; $n=6-8 /$ group; $* P<0.05$ vs. Control; ${ }^{\#} P<0.05$ vs. Day 28 .

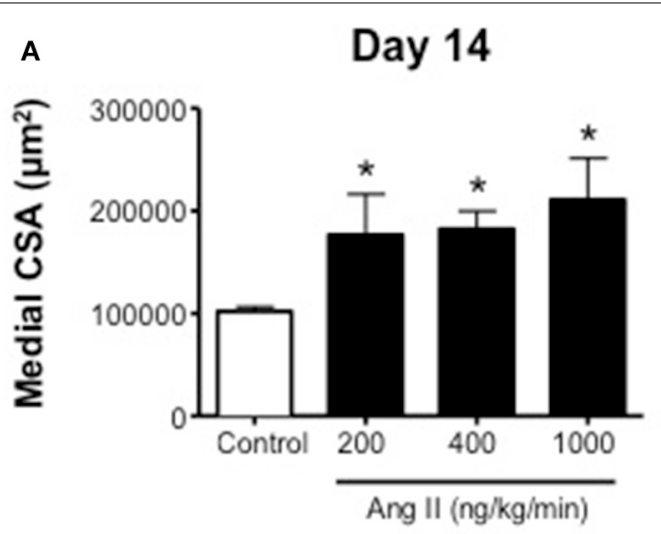

B

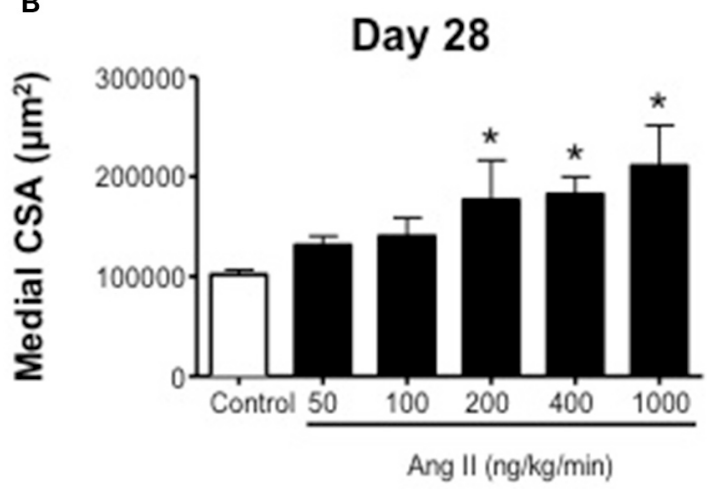

FIGURE 5 | Medial cross-sectional area (aortic) on (A) Day 14 and (B) Day 28 in control and Ang II infused mice. Means \pm SE; $n=3-6 / g r o u p$; $* P<0.05$ vs. Control.

\section{ANG II INFUSION WAS ASSOCIATED WITH INCREASES IN PLASMA IL-6 LEVELS AND VASCULAR MACROPHAGE CONTENT}

Plasma IL-6 levels were relatively low in control mice as would be predicted in the absence of inflammation and averaged $4 \pm 3$ $\mathrm{pg} / \mathrm{ml}$ (Figure 6). Infusion of 200, 400, and $1000 \mathrm{ng} / \mathrm{kg} / \mathrm{min}$ Ang
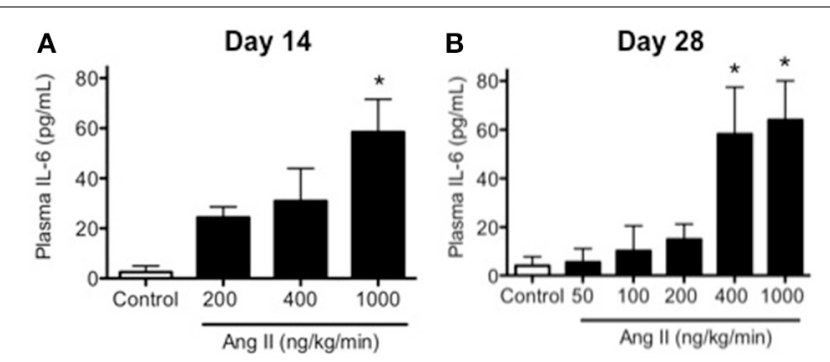

FIGURE 6 | Ang II infusion is associated with dose- and

time-dependent increases in plasma IL-6. Plasma IL-6 levels in control and Ang II infused mice on (A) Day 14 and (B) Day 28 as determined by ELISA. Means \pm SE; $n=3-6 /$ group; ${ }^{*} p<0.05$ vs. Control.

II for 14 Days was associated with 6-, 8-, and 16-fold higher levels of IL- 6 than that in control mice, e.g., IL-6 levels in mice infused with 200, 400, and $1000 \mathrm{ng} / \mathrm{kg} / \mathrm{min}$ Ang II averaged $22 \pm 4,29 \pm$ 8 , and $64 \pm 11 \mathrm{pg} / \mathrm{ml}$, respectively (Figure 6).

Infusion of 50, 100, 200, 400, and $1000 \mathrm{ng} / \mathrm{kg} / \mathrm{min}$ Ang II for 28 Days was associated with plasma IL- 6 levels that averaged $6 \pm 6$, $10 \pm 10,15 \pm 6,58 \pm 19$, and $64 \pm 18 \mathrm{pg} / \mathrm{ml}$, respectively. While plasma IL-6 levels in mice infused 50, 100, and $200 \mathrm{ng} / \mathrm{kg} / \mathrm{min}$ were not different $(P>0.05)$ from that in control mice, infusion of 400 and $1000 \mathrm{ng} / \mathrm{kg} / \mathrm{min}$ were significantly greater than that in control mice. More importantly, plasma IL-6 levels with infusion of $400 \mathrm{ng} / \mathrm{kg} / \mathrm{min}$ Ang II for 28 Days was significantly greater $(P<0.05)$ than that with 14-Day infusion. Plasma IL-6 levels in mice infused with $1000 \mathrm{ng} / \mathrm{kg} / \mathrm{min}$ Ang II for 28 Days were not different $(P>0.05)$ than that with infusion $1000 \mathrm{ng} / \mathrm{kg} / \mathrm{min}$ Ang II for 14 Days (Figure 6). Interestingly, the number of vascular macrophages was significantly higher in mice infused with 400 and $1000 \mathrm{ng} / \mathrm{kg} / \mathrm{min}$ Ang II as compared to that in control mice and mice infused with $200 \mathrm{ng} / \mathrm{kg} / \mathrm{min}$ (Figure 7). Finally, when we examined the relationship between plasma IL-6 levels and plasma Ang II and systolic blood pressure we found that there was a strong correlation between the two (Figure 8). In contrast, there 


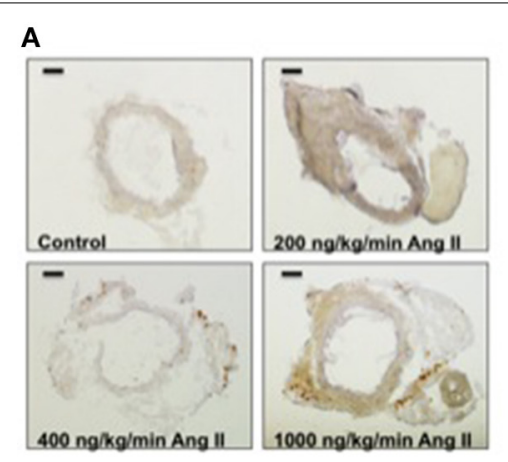

FIGURE 7 | (A) Representative micrographs of vascular macrophage content in carotid arteries from control and Ang II infused $(200,400$, and $1000 \mathrm{ng} / \mathrm{kg} / \mathrm{min}$ ) mice. (B) Quantification of vascular macrophage
B

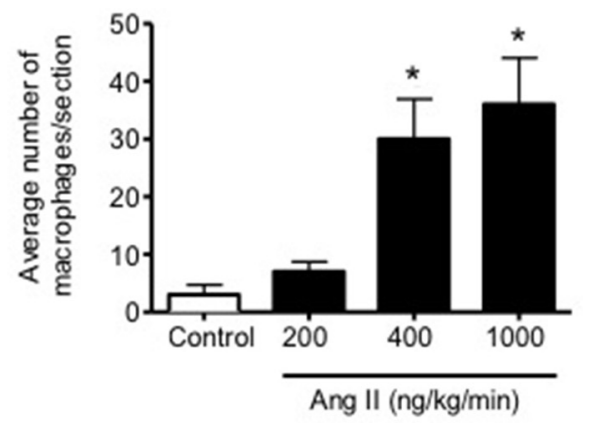

accumulation in carotid arteries from Control and Ang II-infused mice. Magnification: 40x; Scale bar $=500 \mu \mathrm{m}$. $n=3 /$ group; ${ }^{*} p<0.05$ vs. control.
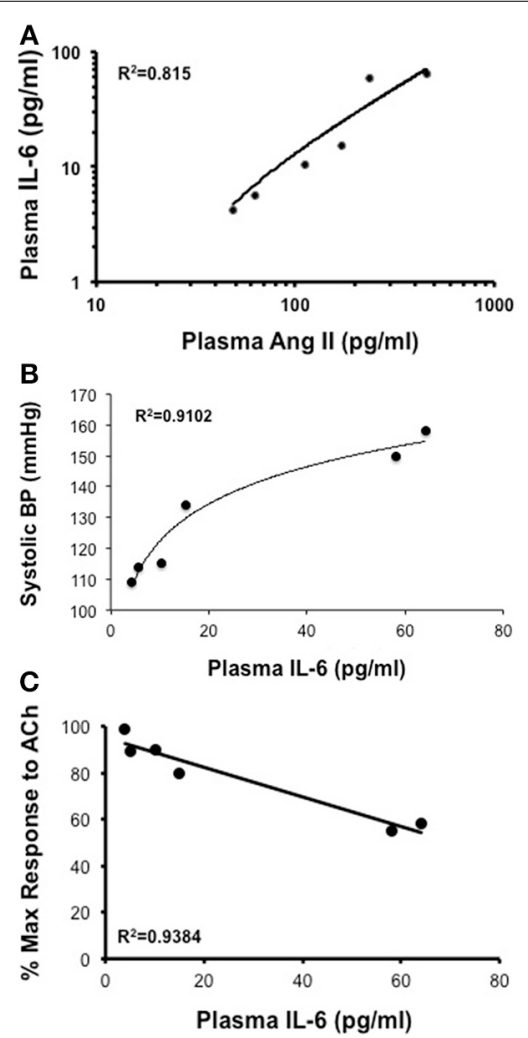

FIGURE 8 | (A,B) While there is a direct correlation between plasma Ang II levels and plasma IL-6 and between plasma IL-6 levels and systolic blood pressure there was $\mathbf{( C )}$ an inverse relationship between plasma IL-6 and endothelial responses to acetylcholine (Ach) following Ang II infusion.

was a strong negative relationship between plasma IL-6 levels and the degree of endothelial function (Figure 8).

\section{DISCUSSION}

There are several important findings of the present study. First, Ang II over a wide range of doses in the mouse was associated with increases in systolic blood pressure that displayed both dose and time dependency. Second, the effective steady-state plasma concentration of Ang II that was required to produce a pressor response was $\geq 170 \mathrm{pg} / \mathrm{ml}$, which was achievable with infusion of doses of Ang II greater than $200 \mathrm{ng} / \mathrm{kg} / \mathrm{min}$. Third, Ang II infusion was associated with minimal to no impairment of endothelial function at low doses $(50-200 \mathrm{ng} / \mathrm{kg} / \mathrm{min})$ and marked impairment (nearly 50\%) at the highest dose of Ang II $(1000 \mathrm{ng} / \mathrm{kg} / \mathrm{min})$. Most interestingly, infusion of Ang II at $400 \mathrm{ng} / \mathrm{kg} / \mathrm{min}$ was the only dose of Ang II that was associated with a temporal impairment of endothelial function. Fourth, plasma IL-6 levels and perivascular macrophage accumulation increased in parallel with blood pressure and plasma Ang II levels. More importantly, impairment of endothelial function was found to correlate directly with IL-6 levels and macrophage accumulation.

\section{DOSE AND TEMPORAL EFFECTS OF ANG II INFUSION ON BLOOD PRESSURE AND PLASMA ANG II LEVELS}

While there is a fair amount of information regarding the effects of infusion of high doses of Ang II (e.g., 400-3600 ng/kg/min) (Kawada et al., 2002; Didion et al., 2005, 2009; Gavazzi et al., 2006; Lee et al., 2006; Guzik et al., 2007; Barhoumi et al., 2011), there is little to no information regarding the effects of lower doses (i.e., $<400 \mathrm{ng} / \mathrm{kg} / \mathrm{min}$ ) on arterial pressure in the mouse. In the present study, we found that infusion of either 50 or $100 \mathrm{ng} / \mathrm{kg} / \mathrm{min}$ Ang II was not associated with alterations in systolic blood pressure up to and including Day 28. The lack of effect of 50 and $100 \mathrm{ng} / \mathrm{kg} / \mathrm{min}$ Ang II on blood pressure could be explained by fact that these doses were not associated with increases in plasma Ang II levels.

In contrast to the effects of lower doses, we found that infusion of intermediate doses of Ang II were associated with biphasic blood pressure responses. For example, $200 \mathrm{ng} / \mathrm{kg} / \mathrm{min}$ had no effect on blood pressure up to Day 13, however blood pressure began to increase on Day 14 and by Days 21 and 28 blood pressure was significantly higher than baseline levels by at least $20 \mathrm{mmHg}$. Similarly, infusion of $400 \mathrm{ng} / \mathrm{kg} / \mathrm{min}$ Ang II also produced a biphasic response, however the pressor response occurred earlier (by at least Day 7$)$ and was of greater magnitude $(\sim 10 \mathrm{mmHg}$ greater than that produced by $200 \mathrm{ng} / \mathrm{kg} / \mathrm{min}$ ). Our data with 
200 and $400 \mathrm{ng} / \mathrm{kg} / \mathrm{min}$ Ang II are consistent with previous findings using similar doses for shorter periods of time ( $<14$ Days) (Kawada et al., 2002; Didion et al., 2009). Our findings also provide new information regarding long-term effects of Ang II infusion up to and including 28 Days.

Plasma Ang II levels were significantly higher in mice infused with 200 and $400 \mathrm{ng} / \mathrm{kg} / \mathrm{min}$ Ang II compared to control mice, suggesting that these doses were sufficient to increase plasma Ang II concentrations and activate AT1 receptors. Our findings also suggest that there is a threshold of plasma Ang II of at least $170 \mathrm{pg} / \mathrm{ml}$ Ang II in order for Ang II to have any significant effect on blood pressure. While plasma Ang II levels tended to be higher in mice infused with $400 \mathrm{ng} / \mathrm{kg} / \mathrm{min}$ they were not significantly different than those in mice infused with $200 \mathrm{ng} / \mathrm{kg} / \mathrm{min}$ Ang II. It is difficult to know how such small incremental differences in plasma Ang II could have such differential effects on blood pressure, however one possibility may involve compartmentalized formation of endogenous Ang II in response to exogenous Ang II infusion. Indeed, Ang II infusion has been shown to stimulate de novo generation of intrarenal Ang II, which has been suggested to contribute to slow pressor response produced by low-dose Ang II infusion and may in part account for the differences in blood pressure produced by 200 and $400 \mathrm{ng} / \mathrm{kg} / \mathrm{min}$ Ang II in the present study (Navar et al., 2011).

Infusion of $1000 \mathrm{ng} / \mathrm{kg} / \mathrm{min}$ Ang II was associated with an immediate (by Day 3 ) increase in systolic blood pressure of nearly $40 \mathrm{mmHg}$, which was maintained throughout the 28-day infusion period. This is consistent with previous studies, including our own, in which $1000 \mathrm{ng} / \mathrm{kg} / \mathrm{min}$ is typically associated with increases in arterial pressure of 40-50 $\mathrm{mmHg}$ (Didion et al., 2005; Schrader et al., 2007). In addition, the increase in arterial pressure achieved with $1000 \mathrm{ng} / \mathrm{kg} / \mathrm{min}$ Ang II appears to represent an upper limit to which blood pressure can be increased with Ang II as infusion of higher doses (e.g., $3600 \mathrm{ng} / \mathrm{kg} / \mathrm{min}$ ) have not been found to increase blood pressure to any greater extent than that achieved with $1000 \mathrm{ng} / \mathrm{kg} / \mathrm{min}$ (Lee et al., 2006).

As one might predict, infusion of $1000 \mathrm{ng} / \mathrm{kg} / \mathrm{min}$ Ang II was associated with the largest increase in plasma Ang II levels (nearly $450 \mathrm{pg} / \mathrm{ml}$ ). While we did not measure plasma Ang II levels other than on Day 28 we would suggest that the levels of Ang II measured on Day 28 most likely represents plasma steady-state levels that are achieved with long-term infusion of Ang II. Surprisingly, the majority of studies using the Ang II infusion model in mice do not measure and/or report plasma Ang II levels (Bush et al., 2000; Crowley et al., 2005, 2006; Didion et al., 2005; Lee et al., 2006; Guzik et al., 2007; Madhur et al., 2010; Barhoumi et al., 2011). In the present study, we measured plasma Ang II levels in all our experimental groups and found that there was a direct correlation between plasma Ang II levels and arterial pressure consistent with observations in other species, including man (Chinn and Dusterdieck, 1972; Bean et al., 1979; Brown et al., 1981; Cholewa and Mattson, 2001; Beevers et al., 2008). The present study is the first to our knowledge to characterize the plasma Ang II concentration-blood pressure response curve following subcutaneous infusion of Ang II in the mouse.

Previous studies have shown that the increase in blood pressure produced by Ang II is mediated in large part by increases in oxidative stress, as scavengers of oxidative stress such as Tempol limit the increase in pressure produced by Ang II infusion (Kawada et al., 2002). The initial increase in blood pressure in response to high pressor doses of Ang II appears to be mediated by Nox2-derived superoxide (Wang et al., 2006). In contrast, Nox1derived superoxide appears to mediate the long-term effects of Ang II on blood pressure as Nox1 deficiency is associated with a rapid increase in blood pressure followed by a return toward baseline levels (Matsuno et al., 2005; Gavazzi et al., 2006). Although we did not examine the role of oxidative stress in the development of hypertension in present study, we would speculate that both Nox1- and Nox2-derived superoxide contribute to independent phases of the hypertension produced in response to Ang II and are mediated via combined and/or temporal activation of vascular, central, as well as renal AT1 receptors (Zimmerman et al., 2002; Ryan et al., 2004; Crowley et al., 2005, 2006).

\section{DOSE AND TEMPORAL EFFECTS OF ANG II ON PLASMA IL-6 LEVELS AND VASCULAR FUNCTION AND MACROPHAGE ACCUMULATION}

In addition to hypertension, Ang II can produce endothelial dysfunction in a number of blood vessels (e.g., aorta, carotid artery, cerebral arterioles) in several species, including mice (Rajagoplan et al., 1996; Su et al., 1998; Didion et al., 2000, 2002, 2005; Wang et al., 2001; Didion and Faraci, 2003; Faraci et al., 2006; Guzik et al., 2007; Barhoumi et al., 2011). Both pharmacologi$\mathrm{cal}$ and genetic approaches have demonstrated that NO (derived primarily from eNOS) is a major mediator of endotheliumdependent relaxation in mouse carotid artery (Faraci et al., 1998). Oxidative stress, such as increases in vascular superoxide levels, limits NO bioavailability and endothelium-dependent relaxation (Didion et al., 2005). We, and others, have shown that interventions directed at reducing vascular superoxide levels produced in response to a number of stimuli, including Ang II, are very effective in restoring $\mathrm{NO}$ and improving endothelial function (Didion and Faraci, 2002, 2005; Didion et al., 2005). Additionally, we have shown that the endothelial dysfunction produced in response to Ang II is mediated primarily through AT1 receptors (Ryan et al., 2004).

High doses of Ang II (i.e., $\geq 490 \mathrm{ng} / \mathrm{kg} / \mathrm{min}$ ) produce marked impairment of endothelial function (Bean et al., 1979; Didion et al., 2005, 2009; Guzik et al., 2007; Schrader et al., 2007; Madhur et al., 2010; Barhoumi et al., 2011), however the effects of lower doses of Ang II on vascular function and structure are poorly defined. Thus, in order to elucidate the temporal processes involved in the development of vascular hypertrophy and endothelial dysfunction in response to Ang II, we examined the effect of multiple doses and time points of Ang II infusion on both of these processes. We elected to examine vascular function in carotid artery, as endothelial dysfunction in this blood vessel is major risk factor for ischemic stroke (Roger et al., 2012; Kernan et al., 2014).

In the present study, we found that, like blood pressure, the degree of endothelial dysfunction produced by Ang II was both dose- and time-dependent. For example, low doses of Ang II (e.g., 50 and $100 \mathrm{ng} / \mathrm{kg} / \mathrm{min}$ Ang II), which did not effect on blood pressure, were also without effect on endothelial function and vascular structure. The lack of effect of these two doses is most 
likely reflective of the fact that they were not associated with increases in plasma Ang II levels and thus not sufficient to activate AT1 receptor signaling. Similarly, doses of Ang II that were associated with slowly developing increases in arterial pressure and plasma Ang II levels (such as $200 \mathrm{ng} / \mathrm{kg} / \mathrm{min}$ Ang II) were surprisingly not associated with alterations in endothelial function despite a marked increase in vascular hypertrophy. Interestingly, infusion of $200 \mathrm{ng} / \mathrm{kg} / \mathrm{min}$ Ang II was not associated with alterations in plasma IL-6 levels or vascular macrophage content compared with that in control mice, suggesting that the increase in blood pressure at these doses occurs independently of increases in inflammatory cells and cytokines. Additionally, our data with $200 \mathrm{ng} / \mathrm{kg} / \mathrm{min}$ Ang II also suggest that vascular hypertrophy precedes the development of hypertension, consistent with the idea that the effect of non-pressor doses of Ang II on vascular structure are due to direct effects of Ang II and independent of blood pressure (Owens and Schwartz, 1982; Berk et al., 1989; Griffin et al., 1991; Su et al., 1998).

Perhaps of equal importance, we found that infusion of $400 \mathrm{ng} / \mathrm{kg} / \mathrm{min}$ Ang II was the only dose in the present study that was associated with temporal impairment of endothelial function. Ang II at this dose was associated with minimal impairment of endothelial function as evidenced by the reduced response to acetylcholine at Day 14. However, endothelial function was impaired to a much greater extent (i.e., a reduction of approximately $50 \%$ in the response to acetylcholine) on Day 28 in mice that were infused $400 \mathrm{ng} / \mathrm{kg} / \mathrm{min}$ Ang II. The degree of impairment associated with 28-day infusion of $400 \mathrm{ng} / \mathrm{kg} / \mathrm{min}$ Ang II was very similar to the degree of endothelial dysfunction produced with either 14 or 28 day infusion of $1000 \mathrm{ng} / \mathrm{kg} / \mathrm{min}$ Ang II, both of which were associated with increases in IL-6 and vascular macrophage levels. Taken together, these findings suggest that inflammation is a major contributor to endothelial dysfunction produced in response to Ang II and is most likely reflective of the degree of hypertension produced by Ang II and/or the length of time hypertension is present.

Consistent with previous studies, infusion of $1000 \mathrm{ng} / \mathrm{kg} / \mathrm{min}$ of Ang II produced approximately 50\% impairment of endothelium-dependent relaxation in response to acetylcholine as early as Day 14 (Didion et al., 2005; Schrader et al., 2007). The degree of impairment produced by $1000 \mathrm{ng} / \mathrm{kg} / \mathrm{min}$ was not affected by the length of time in which Ang II was infused as it was found to be similar on Day 28 as that observed on Day 14. Ang II is known to increase levels of proinflammatory cytokines, such as IL-6, IL-17, and IL-18, in vascular cells (Faraci et al., 1998; Funakoshi et al., 1999; Han et al., 1999; Liu et al., 2003; Sahar et al., 2005; Schrader et al., 2007; Johnson et al., 2013). Consistent with this concept, we found in the present study that IL-6 levels were nearly 60-fold higher in mice infused with $1000 \mathrm{ng} / \mathrm{kg} / \mathrm{min}$ Ang II than that in control mice. Moreover, the increase in plasma IL-6 correlated directly with the degree of endothelial dysfunction and vascular macrophage content.

Functional effects of Ang II-induced increases in IL-6 includes downstream activation of STAT3 (Schieffer et al., 2000; Johnson et al., 2013). STAT3 activation has been shown to have a number of effects, including inhibition of eNOS promoter activity and reductions in eNOS gene expression (Saura et al., 2006), thereby providing a mechanistic link by which IL-6 serves to produce endothelial dysfunction. IL-6 has also been shown to increase expression of AT1 receptors in vascular muscle, which would serve to promote Ang II signaling including increased NFKB activation and IL-6 gene transcription (Han et al., 1999), which would then further enhance IL-6 mediated-reductions in eNOS expression and promote increases in oxidative stress (Wassmann et al., 2004). While we did not examine the contribution of oxidative stress to the impairment of endothelial function, previous studies, including our own, have shown that increases in oxidative stress, particularly Nox2-derived superoxide, contribute to endothelial dysfunction produced by Ang II (Rajagoplan et al., 1996; Didion et al., 2005, 2009; Schrader et al., 2007). While it is difficult to differentiate whether vascular or infiltrating immune cells (as evidence by the increase in vascular macrophage content) associated with 400 and $1000 \mathrm{ng} / \mathrm{kg} / \mathrm{min}$ Ang II) contributed to the increase in plasma IL-6 which then serves to promote increases in oxidative stress, we have shown previously that vascular IL-6 expression contributes to Ang II-induced impairment of endothelial responses (Schrader et al., 2007).

In conclusion, the findings from our study provide a comprehensive examination of the effects of Ang II on both blood pressure and endothelial function in the mouse. Our findings demonstrate that Ang II produces hypertension and endothelial dysfunction in a dose- and time-dependent manner. These findings are important as they serve to delienate the temporal events associated with the development of Ang II-induced endothelial dysfunction. Our data also demonstrate along with increases in arterial pressure that there is a strong correlation between increases in IL- 6 and vascular macrophage accumulation and the degree of endothelial dysfunction produced by Ang II. It will be important to determine whether inflammation promotes oxidative stress or vice versa and whether targeting one or both pathways will be most effective in limiting the negative effects of Ang II on vascular function in human hypertension. This is especially important considering that plasma IL-6 correlates with negative cardiovascular outcomes in humans (Ikeda et al., 1992; Ridker et al., 2000a,b).

\section{ACKNOWLEDGMENTS}

This study was supported by National Institutes of Health grants HL-089884 and HL-107632 (Sean P. Didion). Ms. Gomolak was supported in part by a National Institutes of Health Institutional T32 Training Grant (HL-105324).

\section{REFERENCES}

Barhoumi, T., Kasal, D. A., Li, M. W., Shbat, L., Laurant, P., Neeves, M. F., et al. (2011). T regulatory lymphocytes prevent angiotensin IIinduced hypertension and vascular injury. Hypertension 57, 469-476. doi: 10.1161/HYPERTENSIONAHA.110.162941

Bean, B. L., Brown, J. J., Casals-Stenzel, J., Fraser, R., Lever, A. F., Millar, J. A., et al. (1979). The relation of arterial pressure and plasma angiotensin II concentration: a change produced by prolonged infusion of angiotensin II in the conscious dog. Circ Res. 44, 452-458. doi: 10.1161/01.RES.44.4.452

Beevers, D. G., Maheshwari, M. B., Ryan, P. G., Moss, M. S., and Harding, L. K. (2008). Hypertension due to a renin-secreting juxtaglomerular cell tumor. Am. J. Hypertens 21, 1359-1361. doi: 10.1038/ajh.2008.281

Berk, B. C., Vekshtein, V., Gordon, H. M., and Tsuda, T. (1989). Angiotensin II-stimulated protein synthesis in cultured vascular smooth muscle cells. Hypertension 13, 305-314. doi: 10.1161/01.HYP.13.4.305 
Brown, A., Casals-Stenzel, J., Gofford, S., Lever, A. F., and Morton, J. J. (1981). Comparison of fast and slow pressor effects of angiotensin II in the conscious rat. Am. J. Physiol. 241, 381-388.

Bush, E., Maeda, N., Kuziel, W. A., Dawson, T. C., Wilcox, J. N., DeLeon, H., et al. (2000). CC chemokine receptor 2 is required for macrophage infiltration and vascular hypertrophy in angiotensin II-induced hypertension. Hypertension 36, 360-363. doi: 10.1161/01.HYP.36.3.360

Cassis, L. A., Huang, J., Gong, M. C., and Daugherty, A. (2004). Role of metabolism and receptor responsiveness in the attenuated responses to angiotensin II in mice compared to rats. Reg. Peptides 117, 107-116. doi: 10.1016/j.regpep.2003.09.008

Catt, K. J., Cain, M. D., Zimmet, P. Z., and Cran, M. B. (1969). Blood angiotensin II levels of normal and hypertensive subjects. Br. Med. J. 1, 819-821. doi: 10.1136/bmj.1.5647.819

Catt, K. J., Zimmet, P. Z., Cain, M. D., Cran, E., Best, J. B., and Coghlan, J. P. (1971). Angiotensin II blood-levels in human hypertension. Lancet 297, 459-464. doi 10.1016/S0140-6736(71)91085-3

Chinn, R. H., and Dusterdieck, G. (1972). The response of blood pressure to infusion of angiotensin II: relation to plasma concentrations of renin and angiotensin II. Clin Sci. 42, 489-504.

Cholewa, B. C., and Mattson, D. L. (2001). Role of the renin-angiotensin system during alterations of sodium intake in conscious mice. Am. J. Phys. Regul. Integr. Comp. Physiol. 281, R987-R993.

Crowley, S. D., Gurley, S. B., Herrera, M. J., Ruiz, P., Griffiths, R., Kumar, A. P., et al. (2006). Angiotensin II causes hypertension and cardiac hypertrophy through its receptors in the kidney. Proc. Natl. Acad. Sci. U.S.A. 103, 17985-17990. doi: 10.1073/pnas.0605545103

Crowley, S. D., Gurley, S. B., Oliverio, M. I., Pazmino, A. K., Griffiths, R., Flannery, P. J., et al. (2005). Distinct roles for the kidney and systemic tissues in blood pressure regulation by the renin-angiotensin system. J. Clin. Invest. 115, 1092-1099. doi: 10.1172/JCI200523378

Didion, S. P., and Faraci, F. M. (2002). Effects of NADH and NADPH on superoxide levels and cerebral vascular tone. Am. J. Physiol. Heart Circ Physiol. 282, H688-H695.

Didion, S. P., and Faraci, F. M. (2003). Angiotensin II produces superoxidemediated impairment of endothelial function in cerebral arterioles. Stroke 34 2038-2042. doi: 10.1161/01.STR.0000081225.46324.AA

Didion, S. P., and Faraci, F. M. (2005). Ceramide-induced impairment of endothelial function is prevented by $\mathrm{CuZn}$ superoxide dismutase overexpression. Arterioscler Thromb. Vasc. Biol. 25, 90-95.

Didion, S. P., Kinzenbaw, D. A., and Faraci, F. M. (2005). Critical role for CuZn-superoxide dismutase in preventing angiotensin IIinduced endothelial dysfunction. Hypertension 46, 1147-1153. doi: 10.1161/01.HYP.0000187532.80697.15

Didion, S. P., Kinzenbaw, D. A., Schrader, L. I., Chu, Y., and Faraci, F. M. (2009). Endogenous interleukin-10 inhibits angiotensin IIinduced vascular dysfunction. Hypertension 54, 619-624. doi 10.1161/HYPERTENSIONAHA.109.137158

Didion, S. P., Ryan, M. J., Baumbach, G. L., Sigmund, C. D., and Faraci, F. M. (2002). Superoxide contributes to vascular dysfunction in mice that express human renin and angiotensinogen. Am. J. Physiol. Heart Circ. Physiol. 283, H1569-H1576.

Didion, S. P., Sigmund, C. D., and Faraci, F. M. (2000). Impaired endothelial function in transgenic mice expressing both human renin and human angiotensinogen. Stroke 31, 760-764. doi: 10.1161/01.STR.31.3.760

Faraci, F. M., Lamping, K. G., Modrick, M. L., Ryan, M. J., Sigmund, C. D., and Didion, S. P. (2006). Cerebral vascular effects of angiotensin II: new insights from genetic models. J. Cereb. Blood Flow Metabol. 26, 449-455. doi: 10.1038/sj.jcbfm. 9600204

Faraci, F. M., Sigmund, C. D., Shesely, E. G., Maeda, N., and Heistad, D. D. (1998). Responses of carotid artery in mice deficient in expression of the gene for endothelial NO synthase. Am. J. Physiol. 274, H564-H570.

Funakoshi, Y., Ichiki, T., Ito, K., and Takeshita, A. (1999). Induction of interleukin6 expression by angiotensin II in rat vascular smooth muscle cells. Hypertension 34, 118-125. doi: 10.1161/01.HYP.34.1.118

Galis, Z. S., Thrasher, T., Reid, D. M., Stanley, D. V., and Oh, Y. S. (2013). Investing in high blood pressure research: a national institutes of health perspective. Hypertension 61, 757-761. doi: 10.1161/HYPERTENSIONAHA.111. 00770
Garovic, V., and Textor, S. C. (2005). Renovascular hypertension: current concepts. Semin. Nephrol. 25, 261-271. doi: 10.1016/j.semnephrol.2005.02.010

Gavazzi, G., Banfi, B., Deffert, C., Fiette, L., Schappi, M., Herrmann, F., et al. (2006). Decreased blood pressure in NOX1-deficient mice. FEBS Lett. 580, 497-504. doi: 10.1016/j.febslet.2005.12.049

Geurts, A. M., Cost, G. J., Freyvert, Y., Zeitler, B., Miller, J. C., Choi, V. M., et al. (2009). Knockout rats via embryo microinjection of zinc-finger nucleases. Science 325, 433. doi: 10.1126/science.1172447

Go, A. S., Mozaffarian, D., Roger, V. L., Benjamin, E. J., Berry, J. D., Borden, W. B., et al. (2013). Heart disease and stroke statistics-2013 update: a report from the American Heart Association. Circulation 127, e6-e245. doi: 10.1161/CIR.0b013e318282ab8f

Griffin, S. A., Brown, W. C., MacPherson, F., McGrath, J. C., Wilson, V. G., Korsgaard, N., et al. (1991). Angiotensin II causes vascular hypertrophy in part by a non-pressor mechanism. Hypertension 17, 626-635. doi: 10.1161/01.HYP.17.5.626

Guzik, T. J., Hoch, N. E., Brown, K. A., McCann, L. A., Rahman, A., Dikalov, S., et al. (2007). Role of the $\mathrm{T}$ cell in the genesis of angiotensin II-induced hypertension and vascular dysfunction. J. Exp. Med. 204, 2449-2460. doi: 10.1084/jem.20070657

Han, Y., Runge, M. S., and Brasier, A. R. (1999). Angiotensin II induces interleukin6 transcription in vascular smooth muscle cells through pleiotropic activation of nuclear factor- $\mathrm{B}$ transcription factors. Circ. Res. 84, 695-703. doi: 10.1161/01.RES.84.6.695

Hanselin, M. R., Saseen, J. J., Allen, R. R., Marrs, J. C., and Nair, K. V. (2011). Description of antihypertensive use in patients with resistant hypertension prescribed four or more agents. Hypertension 58, 1008-1013. doi: 10.1161/HYPERTENSIONAHA.111.180497

Ikeda, U., Ohkawa, F., Seino, Y., Yamamoto, K., Hidaka, Y., Kasahara, T., et al. (1992). Serum interleukin 6 levels become elevated in acute myocardial infarction. J. Mol. Cell Cardiol. 24, 579-584. doi: 10.1016/0022-2828(92)91042-4

Johns, C., Gavras, I., Handy, D. E., Salomao, A., and Gavras, H. (1996). Models of experimental hypertension in mice. Hypertension 28, 1064-1069. doi: 10.1161/01.HYP.28.6.1064

Johnson, A. W., Kinzenbaw, D. A., Modrick, M. L., and Faraci, F. M. (2013) Small-molecule inhibitors of signal transducer and activator of transcription 3 protect against angiotensin II-induced vascular dysfunction and hypertension. Hypertension 61, 437-442. doi: 10.1161/HYPERTENSIONAHA.111. 00299

Kawada, N., Imai, E., Karber, A., Welch, W. J., and Wilcox, C. S. (2002). A mouse model of angiotensin II slow pressor response: role of oxidative stress. J. Am. Soc. Nephrol. 13, 2860-2868. doi: 10.1097/01.ASN.0000035087.11758.ED

Kernan, W. N., Ovbiagele, B., Black, H. R., Bravata, D. M., Chimowitz, M. I., Ezekowitz, M. D., et al. (2014). Guidelines for the prevention of stroke in patients with stroke and transient ischemic attack: a guideline for healthcare professionals from the american heart association/american stroke association. Stroke 45, 2160-2236. doi: 10.1161/STR.0000000000000024

Lee, D. L., Strugis, L. C., Labazi, H., Osborne, J. B. Jr., Fleming, C., Pollock, J. S., et al. (2006). Angiotensin II hypertension is attenuated in interleukin6 knockout mice. Am J Physiol. Heart Circ. Physiol. 290, H935-H940. doi: 10.1152/ajpheart.00708.2005

Liu, J., Yang, F., Yang, X. P., Jankowski, M., and Pagano, P. J. (2003). NAD(P)H oxidase mediates angiotensin II-induced vascular macrophage infiltration and medial hypertrophy. Arterioscler Thromb. Vasc. Biol. 23, 776-782. doi: 10.1161/01.ATV.0000066684.37829.16

Madhur, M. S., Lob, H. E., McCann, L. A., Iwakura, Y., Blinder, Y., Guzik, T. J., et al. (2010). Interleukin 17 promotes angiotensin II-induced hypertension and vascular dysfunction. Hypertension 55, 500-507. doi: 10.1161/HYPERTENSIONAHA.109.145094

Matsuno, K., Yamada, H., Iwata, K., Jin, D., Katsuyama, M., Matsuki, M., et al. (2005). Noxl is involved in angiotensin II-mediated hypertension: a study in Nox1-deficient mice. Circulation 112, 2677-2685. doi: 10.1161/CIRCULATIONAHA.105.573709

Navar, L. G., Prieto, M. C., Satou, R., and Kobori, H. (2011). Intrarenal angiotensin II and its contribution to the genesis of chronic hypertension. Curr. Opin. Pharmacol. 11, 180-186. doi: 10.1016/j.coph.2011.01.009

Owens, G. K., and Schwartz, S. M. (1982). Alterations in vascular smooth muscle mass in the spontaneously hypertensive rat. Role of cellular hypertrophy, hyperploidy, and hyperplasia. Circ Res. 51, 280-289. doi: 10.1161/01.RES.51.3.280 
Rajagoplan, S., Kurz, S., Munzel, T., Tarpey, M., Freeman, B. A., Griendling, K. K., et al. (1996). Angiotensin II-mediated hypertension in the rat increases vascular superoxide production via membrane NADH/NADPH oxidase activation. J. Clin. Invest. 97, 1916-1923. doi: 10.1172/JCI118623

Ridker, P. M., Hennekens, C. H., Buring, J. E., and Rifai, N. (2000b). Creactive protein and other markers of inflammation in the prediction of cardiovascular disease in women. N. Engl. J. Med. 342, 836-843. doi: 10.1056/NEJM200003233421202

Ridker, P. M., Rifai, N., Stampfer, M. J., and Hennekens, C. H. (2000a). Plasma concentration of IL- 6 and the risk of future myocardial infarction among apparently healthy men. Circulation 101, 1767-1772. doi: 10.1161/01.CIR.101.15.1767

Roger, V. L., Go, A. S., Lloyd-Jones, D. M., Benjamin, E. J., Berry, J. D., Borden, W. B., et al. (2012). Heart disease and stroke statistics-2012 update: a report from the American Heart Association. Circulation 125, e2-e220. doi: 10.1161/CIR.0b013e31823ac046

Ryan, M. J., Didion, S. P., Mathur, S., Faraci, F. M., and Sigmund, C. D. (2004). Angiotensin II-induced vascular dysfunction is mediated by the AT1A receptor in mice. Hypertension 43, 1074-1079. doi: 10.1161/01.HYP.0000123074.89717.3d

Sahar, S., Dwarakanath, R. S., Reddy, M. A., Lanting, L., Todorov, I., and Natarajan, R. (2005). Angiotensin II enhances interleukin-18 mediated inflammatory gene expression in vascular smooth muscle cells: a novel crosstalk in the pathogenesis of atherosclerosis. Circ. Res. 296, 1064-1071. doi: 10.1161/01.RES.0000168210.10358.f4

Saura, M., Zaragoza, C., Bao, C., Herranz, B., Rodriguez-Puyol, M., and Lowenstein, C. J. (2006). Stat3 mediates interleukin-6 inhibition of human endothelial nitric-oxide synthase expression. J. Biol. Chem. 281, 30057-30062. doi: 10.1074/jbc.M606279200

Schieffer, B., Luchtefeld, M., Braun, S., Hilfiker, A., Hilfiker-Kleiner, D., and Drexler, H. (2000). Role of $\mathrm{NAD}(\mathrm{P}) \mathrm{H}$ oxidase in angiotensin II-induced JAK/STAT signaling and cytokine induction. Circ. Res. 87, 1195-1201. doi: 10.1161/01.RES.87.12.1195

Schrader, L. I., Kinzenbaw, D. A., Johnson, A. W., Faraci, F. M., and Didion, S. P. (2007). IL-6 deficiency protects against angiotensin II-induced endothelial dysfunction and hypertrophy. Arterioslcer. Thromb. Vasc. Biol. 27, 2576-2581. doi: 10.1161/ATVBAHA.107.153080

Sica, D. A. (2010). The evolution of renin-angiotensin blockade: angiotensinconverting enzyme inhibitors as the starting point. Curr. Hypertens Rep. 12, 67-73. doi: 10.1007/s11906-010-0091-9
Smithies, O., and Kim, H. S. (1994). Targeted gene duplication and disruption for analyzing quantitative genetic traits in mice. Proc. Natl. Acad. Sci. U.S.A. 91, 3612-3615. doi: 10.1073/pnas.91.9.3612

Su, E. J., Lombardi, D. M., Siegal, J., and Schwartz, S. M. (1998). Angiotensin II induces vascular smooth muscle cell replication independent of blood pressure. Hypertension 16, 1331-1337. doi: 10.1161/01.HYP.31.6.1331

Wang, D., Chabrashvili, T., Borrego, L., Aslam, S., and Umans, J. G. (2006). Angiotensin II infusion alters vascular function in mouse resistance vessels: roles of O2-- and endothelium. J. Vasc. Res. 43, 109-119. doi: 10.1159/000089969

Wang, H. D., Xu, S., Johns, D. G., Du, Y., Quinn, M. T., Cayatte, A. J., et al. (2001). Role of NADPH oxidase in the vascular hypertrophic and oxidative stress response to angiotensin II in mice. Circ. Res. 88, 947-953. doi: 10.1161/hh0901.089987

Wassmann, S., Stumpf, M., Strehlow, K., Schmid, A., Schieffer, B., Böhm, M., et al. (2004). Interleukin-6 induces oxidative stress and endothelial dysfunction by overexpression of the angiotensin II type 1 receptor. Circ. Res. 94, 534-541. doi: 10.1161/01.RES.0000115557.25127.8D

Zimmerman, M. C., Lazartigues, E., Lang, J. A., Sinnayah, P., Ahmad, I. M., Spitz, D. R., et al. (2002). Superoxide mediates the actions of angiotensin II in the central nervous system. Circ. Res. 91, 1038-1045. doi: 10.1161/01.RES.0000043501.47934.FA

Conflict of Interest Statement: The authors declare that the research was conducted in the absence of any commercial or financial relationships that could be construed as a potential conflict of interest.

Received: 19 August 2014; accepted: 24 September 2014; published online: 29 October 2014.

Citation: Gomolak JR and Didion SP (2014) Angiotensin II-induced endothelial dysfunction is temporally linked with increases in interleukin-6 and vascular macrophage accumulation. Front. Physiol. 5:396. doi: 10.3389/fphys.2014.00396

This article was submitted to Vascular Physiology, a section of the journal Frontiers in Physiology.

Copyright (c) 2014 Gomolak and Didion. This is an open-access article distributed under the terms of the Creative Commons Attribution License (CC BY). The use, distribution or reproduction in other forums is permitted, provided the original author(s) or licensor are credited and that the original publication in this journal is cited, in accordance with accepted academic practice. No use, distribution or reproduction is permitted which does not comply with these terms. 